\title{
Association of Chronic HBV Infection with Chronic Lymphoproliferative Disorders: A Review and Case Report
}

\author{
Snezhana S. Sleptsova, $\mathrm{PhD}, \mathrm{ScD}^{1}$; Vera N. Yadrichinskaya, $\mathrm{PhD}^{1}$; Aida M. Palchina, $\mathrm{PhD}^{1}$; \\ Nataliya V. Borisova, $\mathrm{PhD}, \mathrm{ScD}^{1}$; Inna M. Mulina ${ }^{2}$; Svetlana N. Parfenova ${ }^{2}$; Lev S. Butaev'; \\ Lyubov D. Indeeva, $\mathrm{PhD}^{3}$ \\ ${ }^{1}$ North-Eastern Federal University named after M.K. Ammosov, Yakutsk \\ ${ }^{2}$ Republican Hospital №1, National Center of Medicine, Yakutsk \\ ${ }^{3}$ Yakutsk City Clinical Hospital \\ The Republic of Sakha (Yakutia), Russia
}

\begin{abstract}
This article presents a clinical report on the associated course of chronic hepatitis B virus (HBV) infection with Castleman's disease (CD). We noticed the reactivation of previously latent chronic hepatitis B (CHB) with high replicative activity of HBV DNA during the treatment of lymphoproliferative disease. This clinical case dictates the need for pre-emptive therapy of HBV infection with nucleoside analogues in patients who are receiving chemotherapy. (Int J Biomed. 2016;6(2):128-132.).
\end{abstract}

Key Words: chronic hepatitis B • Castleman's disease • chemotherapy • rituximab • reactivation of viral infection

\section{Introduction}

The aim of our work was a clinical review of the case of HBV reactivation in a patient with Castleman's disease on the background of Rituximab therapy.

Infection caused by HBV is a serious public health challenge all over the world due to its high prevalence and high risk of chronicity with the development of liver cirrhosis and primary liver cancer. The number of HBV carriers in the world is estimated from 300 to 400 million people. The prevalence of HBV carriers ranges from $0.2 \%$ to $1 \%$ in Western Europe and the U.S. to $8 \%$ to $15 \%$ in the Far East, Middle East and Africa. In Russia, the prevalence of HBV infection is from $1.5 \%$ in the European areas to 5\% in Yakutia and the Far East. The total number of people chronically infected with HBV in the Russian Federation is up to 5 million. ${ }^{[1,2]}$

The Republic of Sakha (Yakutia) [the $\mathrm{RS}(\mathrm{Y})$ ] is a disadvantaged region with respect to the incidence of CHB. According to the population register "Chronic viral hepatitis in the RS(Y)," on January 1, 2016, the number of registered

*Corresponding author: Nataliya V. Borisova, $P h D, S c D$ North-Eastern Federal University named after M.K. Ammosov, Yakutsk, The Republic of Sakha (Yakutia), the Russian Federation.

E-mail: borinat@yandex.ru patients who were CHB and HBV carriers was 6,935 and 4,019 , respectively, and the share of HBV infection in the overall structure of chronic hepatitis was $6.8 \%{ }^{\left[{ }^{[3]}\right.}$

Patients with hematologic diseases are a group of individuals at high risk for HBV reactivation or development of acute HBV infection. This is primarily due to the development of secondary immunodeficiency on the background of the underlying disease, transfusion of the blood, and antitumor therapy. ${ }^{[4]}$ The big breakthrough in the treatment of lymphoproliferative diseases occurred after monoclonal antibodies were included in the therapy scheme. One of the first representatives of this group is rituximab. The effectiveness of rituximab was proven in international randomized trials in the treatment of non-Hodgkin's lymphoma. ${ }^{[5]}$

Currently, rituximab is an integral part of the treatment of lymphoproliferative disorders. Rituximab is a chimeric antiCD20 monoclonal antibody having the ability to specifically bind to the transmembrane antigen CD20 expressed on both normal and malignant B-lymphocytes. The drug causes a complement-dependent reaction, which results in the apoptosis of cells carrying the antigen CD20. ${ }^{[6]}$ Rituximab therapy leads to a reduction in the number of B-cells until zero level is reached. ${ }^{[7]}$

The mechanism of reactivation of viral infection in the treatment of Castleman's disease has not been fully 
understood, but it has been suggested that rituximab plays the leading role. The treatment with rituximab leads to a sharp reduction in $\mathrm{B}$ cells in the blood. In study performed by Stasi et al., ${ }^{[8]}$ the effectiveness and side effects of rituximab treatment were investigated in a cohort of 25 individuals with chronic idiopathic thrombocytopenic purpura. Patients were scheduled to receive intravenous rituximab at the dose of 375 $\mathrm{mg} / \mathrm{m}^{2}$ once weekly for 4 weeks. Peripheral blood B cells, evaluated by flow cytometry as $\mathrm{CD} 19^{+}$cells, had a median baseline count of $189 \times 10^{6} / \mathrm{L}$ (range, $56-418 \times 10^{6} / \mathrm{L}$ ). This count declined with treatment, to subnormal levels after the first dose for the majority of patients. Recovery of B cells started between 6 and 9 months, reaching normal values between 9 and 12 months. U. Specks et al. ${ }^{[9]}$ reported on the successful, compassionate use of the anti-CD20 chimeric monoclonal antibody rituximab in a patient with chronic, relapsing cytoplasmic antineutrophil cytoplasmic antibody (cANCA)-associated Wegener's granulomatosis. Complete remission was associated with the disappearance of $\mathrm{B}$ lymphocytes and cANCA.

M. Ghielmini et al. ${ }^{[10]}$ evaluated the effect of singleagent rituximab given at the standard or a prolonged schedule in patients with newly diagnosed, or refractory or relapsed mantle cell lymphoma. After induction treatment with the standard schedule $\left(375 \mathrm{mg} / \mathrm{m}^{2}\right.$ weekly $\left.\times 4\right)$, patients who were responding or who had stable disease at week 12 from the start of treatment were randomly assigned to no further treatment (arm A) or prolonged rituximab administration $\left(375 \mathrm{mg} / \mathrm{m}^{2}\right.$ ) every 8 weeks for four times (arm B). The trial enrolled 104 patients. After induction, clinical response was $27 \%$ with $2 \%$ complete responses. The lymphocytes subset analysis (performed excluding patients with baseline WBC $>10 \times 10^{9} / \mathrm{L}$ who were suspected of having leukemic disease) showed a very early and important reduction of circulating B cells, while T-helper, T-suppressor, and natural killer cells remained approximately stable during the induction phase. Median $\mathrm{B}$-cell levels returned to levels similar to baseline values after 9 months in arm A, while in arm B, the B-cell recovery had still not taken place after 12 months. The difference at 9 months was significant (median, $90.5 \times 10^{6} / \mathrm{L} v 13.9 \times 10^{6} / \mathrm{L} ; P=0.03$ ).

Reactivation of $\mathrm{HBV}$ infection intensifies virus replication in patients with chronic infection or chronic carriers of HBV. The development of clinical and biochemical manifestation of hepatitis is possible in $\mathrm{HBsAg}$ carriers during immunosuppressive therapy, but most of the reactivation has been observed after discontinuation of treatment. A progressive increase in the concentration of serum HBV-DNA is the earliest and most accessible diagnostic indicator for HBV reactivation in clinical practice. At least a 10-fold increase, or exceeding the maximum level of $108 \mathrm{IU} / \mathrm{mL}$, is a necessary diagnostic criterion. In the case of clinical-laboratory $\mathrm{HBV}$ reactivation, the probability of death is from $5 \%$ to $50 \%$ or more, but spontaneous recovery is possible. Especially poor prognosis occurs in hepatitis in patients with pre-existing liver cirrhosis, resulting in acute liver failure on the background of chronic liver failure. ${ }^{[11]}$

In 2001, Dervite et al. reported, for the first time, a case of $\mathrm{HBV}$ reactivation in an $\mathrm{HBs} A g$-negative patient who had received rituximab combination chemotherapy. ${ }^{[12]}$

T.Sera et al. ${ }^{[13]}$ and J.Law et al. ${ }^{[14]}$ have presented independently two patients with lymphoma in whom chemotherapy with rituximab resulted in fulminant hepatitis with a fatal outcome. Thus, J. Law et al. ${ }^{[14]}$ reported a 67-yearold man with B-cell lymphoma who developed hepatitis B reactivation following chemotherapy with cyclophosphamide, adriamycin, vincristine, prednisone and rituximab. Prechemotherapy, the patient was negative for HBsAg, positive for hepatitis B core antibody (anti-HBc) and weakly positive for hepatitis B surface antibody. Despite treatment with lamivudine, the patient died of fulminant hepatic failure. Authors concluded that patients who are negative for $\mathrm{HBsAg}$ but positive for anti-HBc are still at risk for reactivation of latent hepatitis B during and after chemotherapy and may be considered for prophylaxis.

In 2009, Yeo et al. ${ }^{[15]}$ reported that when systemic chemotherapy was used to treat $80 \mathrm{HBsAg-negative} \mathrm{patients}$ with malignant lymphoma, HBV reactivation was observed in $5(6.25 \%)$ of them; all 5 of these patients were HBcAb- and/ or HBsAb-positive, and rituximab and steroid combination chemotherapy had been performed in all 5 patients. Thus, it became evident that reactivation as a result of the combined use of chemotherapy with a high immunosuppressive effect, such as rituximab, or combination therapy with a steroid can occur even in HBsAg-negative patients with $\mathrm{HBcAb}$ and/or $\mathrm{HBsAb}$ positivity. ${ }^{[16]}$

The number of reports regarding $\mathrm{HBV}$ reactivation following chemotherapy has been gradually increasing. Guidelines for the treatment of HBV reactivation following chemotherapy have been published by many groups: the American Association for the Study of Liver Disease (AASLD) Practice Guidelines in 2007; ${ }^{[17]}$ the National Institute of Health (NIH) Consensus Development Conference Management of Hepatitis B in 2008 ${ }^{[18,19]}$ and the European Association for the Study of the Liver (EASL) Clinical Practice Guidelines in 2009. ${ }^{[20]}$ All these guidelines are similar in principal. When chemotherapy is going to be performed, the prophylactic administration of an antiviral drug in HBsAg-positive patients is recommended, and the periodic monitoring of the HBV DNA level and deferred pre-emptive administration of an antiviral drug after the detection of conversion to HBV DNA positivity is recommended for HBsAg-negative patients with $\mathrm{HBcAb}$ and/or $\mathrm{HBsAb}$ positivity.

Currently, interferons are not used to prevent HBVinfection relapse. This is primarily due to their side effects, such as pancytopenia. Among the nucleoside analogues, the greatest experience has been gained in relation to lamivudine. However, one barrier to the success of long-term therapy is the emergence of drug-resistant mutants, which are frequently observed during treatment of $\mathrm{CHB}$ with lamivudine. ${ }^{[20]}$ Current guidelines, therefore, recommend that the most potent drugs with optimal resistance profiles (ie, entecavir [ETV] and tenofovir disoproxil fumarate [TDF]) should be used as first-line monotherapies in CHB. ${ }^{[20-24]}$ These two agents were approved by the US Food and Drug Administration (FDA) for the treatment of CHB on the basis of Phase III clinical study results in 2005 (ETV) and 2008 (TDF). 
No clear evidence exists regarding the termination of the prophylactic administration of antiviral drugs. K. Ono et al. lead clinical example, when the premature cancellation of lamivudine resulted in a re-HBV infection reactivation. ${ }^{[25]}$ Once administration has been continued for 12 months after the completion of chemotherapy and a decrease in the ALT level to within the normal range and conversion to persistent HBV-DNA negativity have been achieved, the termination of the administration of the antiviral drug can be considered.$^{[16,26]}$

Castleman's disease, also known as angiofollicular lymph node hyperplasia, is characterized by non-clonal lymph node proliferation, and was first described by Benjamin Castleman in 1954. ${ }^{[27]}$ Pathologically, it is classified into three types: hyaline-vascular (HV), plasma-cell (PC) and mixed type. ${ }^{[28]}$ Castleman's disease is also categorized into two clinical types: unicentric and multicentric forms (UCD and MCD). ${ }^{[29]}$

The pathogenesis of Castleman disease is not fully understood; however, the central roles of interleukin (IL) 6 in UCD and both IL-6 and human herpesvirus (HHV) 8 in MCD have been well described. ${ }^{[30,31]}$ Dysregulated and overproduced IL-6, particularly in patients with MCD, stimulates the production of acute phase reactants in the liver, resulting in constitutional symptoms, including fever, sweats, and fatigue, and laboratory abnormalities, such as anemia, elevated inflammatory markers, hypergammaglobulinemia, and hypoalbuminemia IL-6 also stimulates B-cell proliferation and induces the expression of vascular endothelial growth factor and increased angiogenesis. IL-6 has emerged as a therapeutic target in Castleman disease based on its critical role in pathogenesis and driving of symptomatology. ${ }^{[32,33]}$

When based on the clinical and pathological subtypes of Castleman's disease, clinical manifestation and management of the disease are distinct. ${ }^{[34]}$ Surgical resection remains the standard therapy for UCD, while systemic therapies are required for the management of MCD. Rituximab monotherapy is the mainstay of therapy; however, novel therapies targeting Il-6 (siltuximab [anti-IL-6 monoclonal antibody] and tocilizumab [anti-IL-6R humanized monoclonal antibody]) may represent a treatment option in the near future. ${ }^{[33,35]}$

According to the Hematology Research Center of the RF Ministry of Health, 76 patients have been reported with Castleman's disease from 1996 to 2014. ${ }^{[35]}$ Accounting for CD patients in the RS(Y) was introduced in 2004. To date, five cases of $\mathrm{CD}$ have been registered in Yakutia, one of which (MCD) we present in this article.

\section{Case presentation}

A 55-year-old man considered himself ill since 2013, when on the background of overall health, headaches, sweating, fatigue, and weakness appeared, and then frequent exacerbations of chronic pyelonephritis were noted. In May 2014, he was hospitalized in the therapeutic department at $\mathrm{YSCH}$ of $\mathrm{RS}(\mathrm{Y})$ with suspected bronchopneumonia. Laboratory blood analysis was performed and the following results were obtained: ESR, $25 \mathrm{~mm} / \mathrm{hr}$; C-reactive protein (CRP), $196.14 \mathrm{mg} / \mathrm{L}$; IgE, 1,439 IU/mL.
Examination revealed an increase in peripheral lymph nodes merging into conglomerates. Lymph nodes were dense and painless, some nodes were enlarged up to $2-3 \mathrm{~cm}$ in diameter. To clarify the diagnosis, the patient was transferred to the Oncology Center, where a biopsy of the right axillary lymph node was performed. Findings of histopathological and immunohistochemical examinations were compatible with the presence of PC type Castleman's disease (Fig.1).

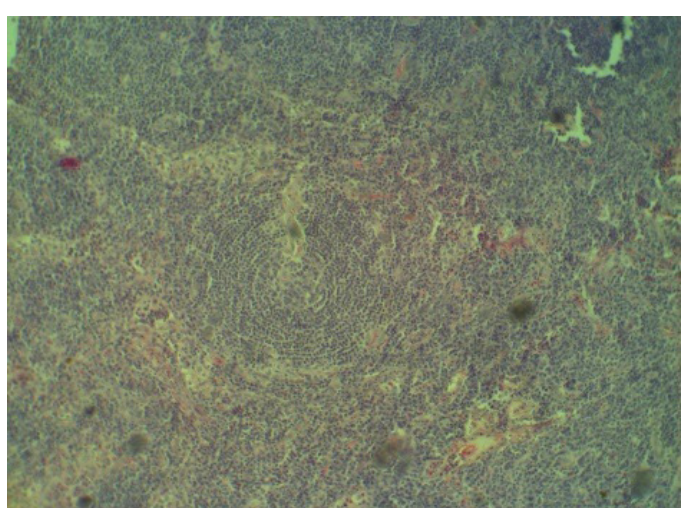

Fig. 1. Lymph node (x20). PC type Castleman's disease. IHC detection of mature CD138+ plasma cells.

To confirm the diagnosis and selection of therapy, the patient was hospitalized in the RCRC, named after NN Blokhin, where according to the histological study of the bone marrow with an immunohistochemical examination, he was diagnosed with HHV-8-negative multicentric Castleman's disease (PC type).

From August 2014 to March 2015, polychemotherapy (PCT) according to the R-VCD scheme (rituximab, bortezomib, cyclophosphamide, dexamethasone) was performed; the next course was applied on the 22nd day. During treatment, against the background of secondary immunodeficiency, the following complications were identified: a generalized herpetic infection (after the second and third courses, and therefore subsequent courses were delayed 1 month each), bacterial pharyngitis (during the third course), neuropathy, and the sensory-vegetative syndrome. On the background of the treatment, clinical-hematological remission was achieved. After five chemotherapy courses, the treatment was continued as monotherapy with rituximab (MabThera), 1 time in 2 months. At the beginning of the second course of rituximab (6 months after the end of the fifth course of PCT), cytolysis (up to 25 standards) was observed. The total bilirubin level increased up to $49.30 \mathrm{mmol} / \mathrm{L}$ and the content of gammaglutamiltranspeptidazy, lactate dehydrogenase, and alkaline phosphatase rose to $451.80 \mathrm{U} / \mathrm{L}$. The patient was hospitalized in the viral hepatitis clinic at the city hospital.

Clinical diagnosis: Chronic viral hepatitis B, HBsAg $(+)$, with high viral load (HBV DNA, 33 million $\mathrm{IU} / \mathrm{mL}$ ). Chronic pyelonephritis. Cyst of the right kidney. Antiviral lamivudine therapy with virologic response, the 4th week (HBV DNA, 4,962 IU/ml). HHV-8-negative multicentric Castleman's disease, the plasma cell type. Condition after 4 courses of R-VCD therapy, a complete remission. 
From anamnesis, we found that HBsAg was first identified on October 9, 2015. Previously, the patient had not been subjected to examination for markers of viral hepatitis. He denied alcohol intake, intravenous drug use, and a history of acute viral hepatitis in childhood. He received dental prosthetics in a private dental office in 2010 . He was married; all members of the family were healthy and did not have hepatitis in anamnesis.

The physical examination revealed a severe general condition. Consciousness and orientation were normal. The findings on physical examination at admission were: height, $165 \mathrm{~cm}$; weight, $71 \mathrm{~kg}$; blood pressure, $95 / 70 \mathrm{mmHg}$; heart rate, 85 beats per minute; respiratory rate, 18 breaths per minute; and body temperature, $36.8^{\circ} \mathrm{C}$. The skin and sclera were pale, slightly icteric. The heart sounds were muffled. Auscultation of the lungs revealed vesicular breathing, which was weakened in the lower lung fields. The abdominal palpation revealed a slight pain in the right upper quadrant and a moderate hepatomegaly; ascites and lymph node enlargement were not observed.

Blood test: ESR, $47 \mathrm{~mm} / \mathrm{h}$; total protein, $69 \mathrm{~g} / \mathrm{L}$; albumin, $34.7 \mathrm{~g} / \mathrm{L}$; total bilirubin, $88.2 \mu \mathrm{mol} / \mathrm{L}$; ALT, $794 \mathrm{IU} / \mathrm{L}$; AST, $411 \mathrm{IU} / \mathrm{L} ; \mathrm{ALP}, 307 \mathrm{IU} / \mathrm{L}$.

Enzyme immunoassay: Viral markers of HBV showed a positive $\mathrm{HBsAg}$, antibodies to $\mathrm{HBcorAG}$ were detected; anti-HCV antibodies were negative; ANA, positive; AMA. negative. Tumor marker results were as follows: AFP, 6.89 IU/ $\mathrm{mL}$; CEA, $5.66 \mathrm{ng} / \mathrm{mL}$; CA 19-9, $5.97 \mathrm{U} / \mathrm{mL}$.

PCR: HBV DNA, positive; viremia, 33, $000000 \mathrm{IU} / \mathrm{mL}$

Abdominal sonography revealed a moderate hepatosplenomegaly; the structure of the liver was nonuniform and the diffuse changes of parenchyma were noted. During EGD, we identified varicose veins of the esophagus (degree I). Contrast-enhanced CT of the abdomen revealed diffuse changes in the liver parenchyma, calcification located in segment 7 of the liver, and perivesical effusion, cyst of the right kidney, and additional renal arteries of both kidneys.

Antiviral therapy with lamivudine (150 mg twice daily for 35 days) was conducted and showed improvement of the general condition, reduction of intoxication, and signs of liver failure. Viral load decreased to $4,962 \mathrm{IU} / \mathrm{mL}$. The patient was discharged to outpatient treatment with a subsequent transition to entecavir therapy under the control of biochemical and virological parameters.

This example demonstrates the clinical manifestation of chronic HBV infection on the background of immunosuppressive therapy for Castleman's disease. In identifying anti-HBcor, even in the absence of HBsAg prior to and during chemotherapy, it is necessary to determine the level of HBV-DNA every 1-3 months. ${ }^{[17-20,35]}$ Lamivudine has been used longer than other drugs in treatment for reactivation of HBV infection, but within three years of the application of this drug, resistance is developed in $53 \%$ to $76 \%$ of cases, which indicates the expedience of lamivudine therapy for a short course and at low level of viremia. Thus, a high viral load and the need for antiviral therapy for at least 12 months justified the switch to another drug in our case; the use of entecavir or tenofovir with a high barrier resistance was advisable. During therapy, it is recommended to monitor the level of serum ALT (at least 1 time in 2 weeks for the first month of treatment, and then 1 time per month) and HBV DNA (during the 4th, 8th and 12 th weeks from the start of antiviral therapy, and after that at least 1 time in 3 months on the background of therapy).

\section{Conclusion}

Since RS (Y)) is a disadvantaged region with respect to the incidence of $\mathrm{CHB}$, all patients with hematologic malignancies should be tested for serologic markers of viral hepatitis $\mathrm{B}$ and $\mathrm{C}$ before the start of chemotherapy. HVB seronegative patients should be vaccinated according to an accelerated vaccination schedule.

If anti-HBcor or NBsAg is identified, viral load (HBV DNA) should be determined. However, regardless of the level of viremia, a pre-emptive treatment with nucleoside analogues is recommended. This therapy should be initiated prior to the appointment of chemotherapy, for the entire period of chemotherapy, and for 12 months after chemotherapy. In such cases, it is necessary to introduce algorithms to manage these patients, with compliance with continuity in the work of infectologists, oncologists and hematologists.

\section{Competing interests}

The authors declare that they have no competing interests.

\section{References}

1. Ivashkin VT, Bueverov AO. Rational pharmacotherapy in hematology. M.: Litterra; 2009. [in Russian].

2. Abdurakhmanov DT. Chronic hepatitis B and D. M.: GEOTAR-Media; 2010, 288pp. [in Russian].

3. Sleptsova SS. Viral hepatitis in the Republic of Sakha (Yakutia). Abstract of ScD Thesis. St. Petersburg; 2013. [in Russian].

4. Yeo W, Johnson PJ. Diagnosis, prevention and management of hepatitis $B$ virus reactivation during anticancer therapy. Hepatology 2006; 43(2): 209-20.

5. Marcus R, Imrie K, Belch A, Cunningham D, Flores E, Catalano J, et al. CVP chemotherapy plus rituximab compared with CVP as first-line treatment for advanced follicular lymphoma. Blood. 2005; 105(4):1417-23.

6. Fanale MA, Younes A. Monoclonal antibodies in the treatment of non-Hodgkin's lymphoma. Drugs. 2007; 67(3):333-50.

7. Aries PM, Hellmich B, Voswinkel J, Both M, Nölle B, Holl-Ulrich K, et al. Lack of efficacy of rituximab in Wegener's granulomatosis with refractory granulomatous manifestations. Ann Rheum Dis. 2006; 65(7): 853-8.

8. Stasi R, Pagano A, Stipa E, Amadori S. Rituximab chimeric anti-CD20 monoclonal antibody treatment for adults with chronic idiopathic thrombocytopenic purpura. Blood. 2001 Aug 15;98(4):952-7.

9. Specks U, Fervenza FC, McDonald TJ, Hogan MC. Response of Wegener's granulomatosis to anti-CD20 chimeric monoclonal antibody therapy. Arthritis Rheum. 2001; 44(12):2836-40.

10. Ghielmini M, Schmitz SF, Cogliatti S, Bertoni F, Waltzer 
U, Fey MF, et al. Effect of single-agent rituximab given at the standard schedule or as prolonged treatment in patients with mantle cell lymphoma: a study of the Swiss Group for Clinical Cancer Research (SAKK). J Clin Oncol. 2005; 23(4):705-11. 11. Lok AS, Ward JW, Perrillo RP, McMahon BJ, Liang TJ. Reactivation of Hepatitis B during immunosuppressive therapy: potentially fatal yet preventable. Ann Intern Med. 2012; 156(10):743-5.

12. Dervite I, Hober D, Morel P. Acute hepatitis B in a patient with antibodies to hepatitis B surface antigen who was receiving rituximab. N Engl J Med. 2001;344(1):68-9.

13. Sera T, Hiasa Y, Michitaka K, Konishi I, Matsuura K, Tokumoto Y, et al. Anti-HBs-positive liver failure due to hepatitis $\mathrm{B}$ virus reactivation induced by rituximab. Intern Med. 2006;45(11):721-4.

14. Law JK, Ho JK, Hoskins PJ, Erb SR, Steinbrecher UP, Yoshida EM. Fatal reactivation of hepatitis B postchemotherapy for lymphoma in a hepatitis B surface antigennegative, hepatitis B core antibody-positive patient: potential implications for future prophylaxis recommendations. Leuk Lymphoma. 2005; 46(7):1085-9.

15. Yeo W, Chan TC, Leung NW, Lam WY, Mo FK, Chu MT, et al.Hepatitis B virus reactivation in lymphoma patients with prior resolved hepatitis B undergoing anticancer therapy with or without rituximab. J Clin Oncol. 2009; 27(4):605-11.

16. Ikeda M. Reactivation of hepatitis $B$ virus in patients receiving chemotherapy. Jpn J Clin Oncol. 2013; 43(1):8-16.

17. Lok AS, McMahon BJ. Chronic hepatitis B. Hepatology 2007;45:507-39.

18. Belongia EA, Costa J, Gareen IF, Grem JL, Inadomi JM, Kern ER, et al. NIH consensus development statement on management of hepatitis B. NIH Consens State Sci Statements. 2008 Oct 22-24;25(2):1-29.

19. Hoofnagle JH. Reactivation of hepatitis B. Hepatology 2009;49(5 Suppl.):S156-65.

20. European Association for the Study of the Liver. EASL clinical practice guidelines: management of chronic hepatitis B. J Hepatol 2009;50:227-42.

21. Lok AS, McMahon BJ. Chronic hepatitis B: update 2009. Hepatology. 2009;50(3):661-2.

22. Moses SE, Lim ZY, Sudhanva M, Devereux S, Ho AY, Pagliuca A, et al. Lamivudine prophylaxis andtreatment of hepatitis B virus-exposed recipients receiving reduced intensity conditioning hematopoietic stem cell transplants with alemtuzumab. J Med Virol. 2006; 78(12):1560-3.

23. Wong VW, Wong GL, Yiu KK, Chim AM, Chu SH,
Chan HY, et al. Entecavir treatment in patients with severe acute exacerbation of chronic hepatitis B. J Hepatol. 2011; 54(2):236-42.

24. Mastroianni CM, Lichtner M, Citton R, Del Borgo C, Rago A, Martini H, et al. Current trends in management of hepatitis $\mathrm{B}$ virus reactivation in the biologic therapy era. World J Gastroenterol. 2011;17(34):3881-7.

25. Ono K, Iyama S, Matsunaga T, Sato T, Sato Y, Okuda T, et al. Reactivation of hepatitis $\mathrm{B}$ virus due to rituximab plus CHOP after preemptive lamivudine administration in a patient with diffuse large B-cell lymphoma. Gan To Kagaku Ryoho 2007; 34(9):1509-12. [Article in Japanese].

26. Idilman R. Duration of lamivudine prophylaxis in in active hepatitis $\mathrm{B}$ virus carriers with haematooncological malignancies who receive chemotherapy. Gut (letter) 2006; 55: $1208-9$.

27. Castelman B, Towne VW. Case records of the Massachusetts General Hospital: Case No. 40231. N Engl J Med 1954; 250(23):1001-5.

28. Keller AR, Hochholzer L, Castleman B. Hyaline-vascular and plasma-cell types of giant lymph node hyperplasia of the mediastinum and other locations. Cancer 1972;29:670-683.

29. Gaba AR, Stein RS, Sweet DL, Variakojis D. Multicentric giant lymph node hyperplasia. Am J Clin Pathol 1978;69:86-90. 30. Chang Y, Cesarman E, Pessin MS, Lee F, Culpepper J, Knowles DM, Moore PS. Identification of herpesviruslike DNA sequences in AIDS-associated Kaposi's sarcoma. Science. 1994; 266(5192):1865-9.

31. Polizzotto MN, Uldrick TS, Wang V, Aleman K, Wyvill $\mathrm{KM}$, Marshall V, et al. Human and viral interleukin- 6 and other cytokines in Kaposi sarcoma herpesvirus-associated multicentric Castleman disease. Blood. 2013;122(26):4189-98. 32. Yoshizaki K, Matsuda T, Nishimoto N, Kuritani T, Taeho L, Aozasa K, et al. Pathogenic significance of interleukin-6 (IL-6/BSF-2) in Castleman's disease. Blood. 1989;74(4):1360-7.

33. Soumerai JD, Sohani AR, Abramson JS. Diagnosis and management of Castleman disease. Cancer Control. 2014 Oct;21(4):266-78.

34. van Rhee F, Stone K, Szmania S, Barlogie B, Singh $\mathrm{Z}$. Castleman disease in the 21st century: an update on diagnosis, assessment, and therapy. Clin Adv Hematol Oncol 2010;8:486-498.

35. Ivashkin BT, Yushchuk ND. Recommendations for the diagnosis and treatment of adult patients with hepatitis B and C. M.: GEOTAR-Media; 2015, 144 pp. [in Russian]. 